Published in final edited form as:

N Engl J Med. 2004 November 04; 351(19): 1962-1971. doi:10.1056/NEJMoa040979.

\title{
Mass Treatment with Single-Dose Azithromycin for Trachoma
}

\author{
Anthony W. Solomon, M.B., B.S., Ph.D., \\ London School of Hygiene and Tropical Medicine, London; Kilimanjaro Christian Medical College, \\ Tumaini University, Moshi, Tanzania; Huruma Hospital, Mkuu, Rombo, Tanzania \\ Martin J. Holland, Ph.D., \\ London School of Hygiene and Tropical Medicine, London; Medical Research Council \\ Laboratories, Fajara, the Gambia \\ Neal D.E. Alexander, Ph.D., \\ London School of Hygiene and Tropical Medicine, London
}

Patrick A. Massae, D.C.E.H.

Huruma Hospital, Mkuu, Rombo, Tanzania; Huruma Hospital, Mkuu, Rombo, Tanzania

Aura Aguirre, Ph.D., Angels Natividad-Sancho, M.Sc., Sandra Molina, M.Sc.

London School of Hygiene and Tropical Medicine, London

Salesia Safari, M.D.

Huruma Hospital, Mkuu, Rombo, Tanzania

John F. Shao, M.D., Ph.D., Paul Courtright, Dr.P.H.

Kilimanjaro Christian Medical College, Tumaini University, Moshi, Tanzania

Dr.P.H. Rosanna W. Peeling, Ph.D.,

Special Programme for Research and Training in Tropical Diseases, World Health Organization, Geneva; National Microbiology Laboratory, Health Canada, Winnipeg, Man

Sheila K. West, Ph.D.,

Dana Center for Preventive Ophthalmology, Johns Hopkins University, Baltimore

Robin L. Bailey, F.R.C.P., Ph.D.

London School of Hygiene and Tropical Medicine, London; Medical Research Council

Laboratories, Fajara, the Gambia

Allen Foster, F.R.C.S., F.R.C.Ophth., David C.W. Mabey, D.M., F.R.C.P.

London School of Hygiene and Tropical Medicine, London

\section{Abstract}

Background-Trachoma, caused by repeated ocular infection with Chlamydia trachomatis, is an important cause of blindness. Current recommended dosing intervals for mass azithromycin treatment for trachoma are based on a mathematical model.

Address reprint requests to Dr. Solomon at the Clinical Research Unit, London School of Hygiene and Tropical Medicine, Keppel St., London WC1E 7HT, United Kingdom, or at anthony.solomon@1shtm.ac.uk. 
Methods-We collected conjunctival swabs for quantitative polymerase-chain-reaction assay of C. trachomatis before and 2, 6, 12,18, and 24 months after mass treatment with azithromycin in a Tanzanian community in which trachoma was endemic. For ethical reasons, at 6, 12, and 18 months, we gave tetracycline eye ointment to residents who had clinically active trachoma.

Results-At baseline, 956 of 978 residents (97.8 percent) received either one oral dose of azithromycin or (if azithromycin was contraindicated) a course of tetracycline eye ointment. The prevalence of infection fell from 9.5 percent before mass treatment to 2.1 percent at 2 months and 0.1 percent at 24 months. The quantitative burden of ocular $C$. trachomatis infection in the community was 13.9 percent of the pretreatment level at 2 months and 0.8 percent at 24 months. At each time point after baseline, over 90 percent of the total community burden of $C$. trachomatis infection was found among subjects who had been positive the previous time they were tested.

Conclusions-The prevalence and intensity of infection fell dramatically and remained low for two years after treatment. One round of very-high-coverage mass treatment with azithromycin, perhaps aided by subsequent periodic use of tetracycline eye ointment for persons with active disease, can interrupt the transmission of ocular $C$. trachomatis infection.

Trachoma is a chronic keratoconjunctivitis caused by the bacterium Chlamydia trachomatis. Resolution of ocular chlamydial infections may be accompanied by scarring of the conjunctivae. Over many years, contraction of upper-lid scars produced during multiple episodes of infection ${ }^{1}$ causes the eyelashes of some patients to deviate inward so that they abrade the globe. This complication, termed "trichiasis," leads to scarring of the cornea. Trachoma is the most common infectious cause of blindness. ${ }^{2}$

Until the 1990s, attempts to control trachoma with antibiotics yielded mostly disappointing results. Mass administration of oral sulfonamides in North America in the 1930s and 1940s was associated with an unacceptably high incidence of severe adverse reactions, including the Stevens-Johnson syndrome. ${ }^{3,4}$ Mass distribution of tetracycline eye ointment (subsequently referred to as tetracycline) in a number of countries in the 1950s and 1960s 5 was also ultimately unsuccessful. Because tetracycline is unpleasant to apply and requires many weeks' use to be effective, compliance is poor. The discovery that single-dose azithromycin is at least as effective as a prolonged course of tetracycline ${ }^{6-10}$ was therefore a major advance.

Using a mathematical model to estimate the frequency of mass treatment with azithromycin that is required to eliminate trachoma, Lietman et al. suggested twice-yearly treatment in communities in which more than 50 percent of children have clinically active trachoma and annual treatment in communities in which less than 35 percent of children have active trachoma. ${ }^{11}$ The model, however, assumed a treatment efficacy of 95 percent, a homogeneous distribution of cases, and the absence of immigration. The model was also based on analyses of disease, although there is poor correlation between disease and $C$. trachomatis infection. ${ }^{12-14}$ The usual current practice, however, is to offer annual treatment wherever the prevalence of active trachoma among children is 20 percent or greater. Empirical data on the rates of reinfection after mass treatment with azithromycin are required. We used a quantitative polymerase-chain-reaction (PCR) assay to examine the 
effect of high-coverage mass distribution of azithromycin on ocular chlamydial infection in a community in Tanzania in which trachoma was endemic.

\section{Methods}

The study was approved by the ethics committees of the Kilimanjaro Christian Medical Centre, Moshi, Tanzania, and the London School of Hygiene and Tropical Medicine, London. Written informed consent was obtained from all subjects or their parents.

\section{Population, Enrollment, Baseline Examination, and Treatment}

We conducted the study in Kahe Mpya subvillage, Rombo District, Tanzania. This community has been described previously. ${ }^{15}$ In July 2000, we examined each consenting resident for trachoma, using the simplified system of the World Health Organization. ${ }^{16}$ This grading system includes five signs: trachomatous inflammation-follicular, defined as five or more follicles at least $0.5 \mathrm{~mm}$ in diameter in the central plate; trachomatous inflammationintense, defined as pronounced inflammatory thickening of the upper tarsal conjunctiva obscuring at least half the normal deep tarsal vessels; trachomatous scarring; trachomatous trichiasis; and corneal opacity. We then swabbed the tarsal conjunctiva of each subject's right eye, using a highly standardized swabbing technique. ${ }^{15}$ Every nonpregnant resident 12 months of age or older was then offered one directly observed oral dose of $20 \mathrm{mg}$ of azithromycin per kilogram of body weight (maximum, $1 \mathrm{~g}$ ). Children younger than 12 months of age and pregnant women were not given azithromycin, but instead were offered two tubes of 1 percent tetracycline, with instructions to apply the ointment twice daily for 6 weeks. Azithromycin was donated by Pfizer through the International Trachoma Initiative, Dar es Salaam, Tanzania. Neither of these organizations had any role in the study design, data analysis, manuscript preparation, or the publication decision. Tetracycline was obtained on the open market. All treatment was provided free to subjects.

\section{Follow-up}

We conducted a census review monthly for 24 months after treatment. At each review, we checked the residence status of each registered subject and offered enrollment to new residents (persons who had arrived and infants who had been born in the previous month). Conjunctival swabs were obtained from the new residents at the time of enrollment. For all subjects, follow-up examination and swabbing were performed by the same examiner at 2,6, 12,18 , and 24 months. Subjects who moved out of the subvillage were not seen at followup. Our cohort therefore consisted of residents seen at intervals through 24 months of follow-up (an open, or dynamic, population), ${ }^{17}$ rather than the people who were residents at baseline. Because continuous inflammation predicts the development of conjunctival scarring, ${ }^{18}$ for ethical reasons, at 6,12 , and 18 months, we gave two tubes of tetracycline to subjects with active disease (as defined by the presence of trachomatous inflammationfollicular, trachomatous inflammation-intense, or both in either eye ${ }^{16}$ ).

We took stringent precautions to prevent carryover contamination between subjects. ${ }^{15}$ Swabs were stored dry on ice $\left(4^{\circ} \mathrm{C}\right)$ in the field, frozen at $-20^{\circ} \mathrm{C}$ within eight hours after collection, and then flown on ice to London. PCR methods have been presented in detail 
elsewhere. ${ }^{15}$ Briefly, we undertook primary screening for the presence or absence of $C$. trachomatis DNA, using a highly sensitive qualitative PCR assay (Amplicor, Roche Molecular Systems). ${ }^{19,20}$ For positive and equivocal samples, we extracted DNA from the Amplicor preparation using the QIAamp kit (Qiagen) and amplified it in the Light-Cycler (Roche) using primers specific for a 123-bp sequence within constant domain 3 of the single-copy chromosomal gene ompl. For all but 20 Amplicor-positive samples (15 samples obtained at baseline and 5 obtained at two months), quantification was performed twice, on two independent 4- $\mu$ aliquots, amplified on separate runs; we derived the final number of copies by calculating the geometric mean of the two estimates.

\section{Statistical Analysis}

We double-entered data in Microsoft Access software (version 97 SR-2); discrepancies were checked against the original forms. We performed statistical analyses using Stata 7 software. To compare proportions of subjects with infection and subjects with disease at different time points, allowing for the partial matching of data, we used logistic generalized estimating equations. ${ }^{21}$ The exception was the comparison of infection at 24 months (when only one subject was positive) with infection at other time points. For this analysis, we included only matched records and used the exact binomial version of McNemar's test. ${ }^{22}$ Our summary statistic for the quantitative burden of ocular $C$. trachomatis infection in the community was an adjusted geometric mean derived by adding 1 copy of omp 1 per milliliter ( 0.55 copy per swab) to each subject's conjunctival load, taking the geometric mean, then subtracting the same value (1 copy of omp 1 per milliliter). We calculated confidence intervals for this index by means of bootstrap analysis, with 10,000 replicates.

\section{Results}

\section{Enrollment, Treatment, and Follow-up}

At baseline, as previously reported, ${ }^{15}$ we examined and obtained a conjunctival swab from 956 of the 978 residents of Kahe Mpya (97.8 percent). Of the 956 subjects, 916 (95.8 percent of subjects and 93.7 percent of residents) were then given azithromycin, and 39 (4.1 percent of subjects and 4.0 percent of residents) were given tetracycline. In total, 955 (97.6 percent of residents) were given antibiotics; 160 -year-old woman underwent swabbing but declined treatment.

Over a follow-up period of 24 months, 195 new residents (113 immigrants and 82 newborns) were registered. The number of new residents, however, was approximately balanced by the number of deaths and emigrations. The crude emigration rate was 0.23 per person-year; emigrants returned at a rate of 0.62 per person-year. The rate of participation at follow-up was high (Table 1).

\section{Changes in the Prevalence of Infection}

The prevalence of $C$. trachomatis conjunctival infection decreased progressively over time (Table 1). The decrease from baseline to two months was significant $(\mathrm{P}<0.001)$. At 6, 12, 18, and 24 months, the prevalence of infection remained significantly lower than it had been 
before treatment $(\mathrm{P}<0.001$ for each comparison), and in each instance it was below, but not significantly below, that recorded for the previous round.

\section{Changes in the Intensity of Infection}

In general, at each time point, the highest chlamydial loads were found in the youngest age groups (Fig. 1). No subject 16 years of age or older had an ocular chlamydial infection at 6 , 12 , or 24 months, though two women (age, 62 and 88 years) were infected at 18 months.

The community burden of ocular $C$. trachomatis infection dropped to 13.9 percent of the pretreatment level 2 months after mass treatment and thereafter continued to decrease; the burden was 8.7 percent of the baseline level at 6 months, 4.7 percent at 12 months, 3.6 percent at 18 months, and 0.8 percent at 24 months (Table 1 and Fig. 2A). Decreases in this index were observed in all age and sex groups (Fig. 2B).

\section{Changes in the Prevalence of Active Disease}

At baseline, 195 of 956 subjects (20.4 percent) had active disease (trachomatous inflammation-follicular, trachomatous inflammation-intense, or both in either eye ${ }^{16}$ ). The overall prevalence of active trachoma was significantly lower at each follow-up point than it had been at baseline ( $\mathrm{P}<0.001$ for each comparison). The overall prevalence at 12 months (94 cases of active disease among 907 subjects, or 10.4 percent) was significantly higher than it was at either 6 months (54 cases among 879 subjects, or 6.1 percent) or 18 months (54 among 889, or 6.1 percent; $\mathrm{P}<0.001$ for each comparison). The peak prevalence of active disease occurred between the ages of one and four years at each time point (Fig. 3).

\section{Intensity of Infection in Subgroups of the Population}

At baseline, 98.1 percent of the community burden of ocular chlamydial infection was accounted for by 174 subjects with clinically active disease in the swabbed eye. Subjects with clinically active disease accounted for proportionately less of the total chlamydial burden at 2, 6, and 12 months, but at 18 and 24 months, when there were very few infections, this subgroup accounted for 100 percent of the total (Table 2). At all time points, the community burden of infection was disproportionately borne by children under the age of 10 years (Table 2 ).

\section{Effect of Antibiotics on the Transmission of Infection}

There were few new infections after mass treatment (Table 2). At each time point after baseline, over 90 percent of the total burden of $C$. trachomatis was found among subjects who had been positive the previous time they were tested. Of 195 subjects who were enrolled after baseline, none of the newborns and only two of the immigrants were positive at enrollment: one was a 16-year-old girl who arrived just before the 2-month census review (test result, 15 copies of omp 1 per swab at 2 months), and the other was a 13-year-old girl who arrived just after the 5-month census review (test result, 19 copies of omp 1 per swab at 6 months and 162 copies per swab at 12 months). Neither had any sign of active disease; neither received tetracycline. Household contacts of these subjects were negative for $C$. trachomatis at the follow-up evaluations after their arrival, suggesting that the girls were not sources of secondary infection. At 12 months, the test result of 162 copies of ompl per swab 
for the 13-year-old represented a large proportion of the total burden of infection (Table 2), given that the total number of copies of omp 1 in the community was 503 at that time, as compared with $1,578,724$ at baseline.

At six months, 54 subjects were given tetracycline, including 7 subjects who were positive for $C$. trachomatis and who accounted for nearly half the total community burden of infection at that time (Table 2). At the next follow-up evaluation (12 months), these 54 subjects still accounted for 15.0 percent of the total community burden. At 12 months, 94 subjects were given tetracycline, including 5 whose ocular infection represented 61.9 percent of the total community burden; at the next follow-up, the ocular infection in this subgroup represented 99.8 percent of the total community burden. At 18 months, 54 subjects were given tetracycline, including 3 whose ocular infection represented 99.8 percent of the total community burden; 1 of those 3 was still infected (and was the only infected subject) at 24 months.

\section{Discussion}

In this Tanzanian community in which trachoma was endemic, the prevalence of ocular $C$. trachomatis infection fell dramatically after mass treatment with azithromycin. The decline in the prevalence of infection continued for two years, at which time there was only 1 infected subject among 842 who were tested. This observation contrasts starkly with the predicted pattern of rapid community reinfection used in a model of the effect of mass treatment. ${ }^{11}$ Subjects who were positive on PCR testing after treatment had relatively lowintensity infections, as demonstrated by the community ocular $C$. trachomatis load, which was 0.423 at baseline, 0.059 (13.9 percent of the baseline value) two months after treatment, and 0.003 ( 0.8 percent of the baseline value) at two years. These large, progressive decreases in the prevalence and intensity of infection suggest that transmission was stopped. This hypothesis is supported by analyses of the distribution of infection: at each evaluation after treatment, over 90 percent of the ocular chlamydial burden was found among subjects who had had a positive result the previous time they were tested, and less than 10 percent among those who had either not been tested before or whose previous test had been negative. There are no known animal or environmental reservoirs of human $C$. trachomatis strains. ${ }^{23,24}$

The most likely explanation for the interruption in the transmission of infection is the extremely high antibiotic coverage achieved with mass treatment. Because the study was not designed to test the efficacy of antibiotic treatment, there was no placebo group, and alternative explanations for our findings should be considered. First, neither enhanced personal hygiene among study participants nor a reduction in the density of eye-seeking flies in the village, each of which may reduce the transmission of C. trachomatis, ${ }^{25}$ can be ruled out. However, studies demonstrating the effectiveness of these measures involved highly intensive interventions ${ }^{26,27}$; no such interventions were undertaken in the village during our study. Second, we cannot rule out a small contribution from a regional secular trend. ${ }^{28}$ Third, a proportion of the observed longevity of the reduction in the chlamydial burden could be ascribed to tetracycline treatment in residents with active cases at 6,12, and 18 months. In each instance, the prevalence of infection in those given tetracycline was lower six months after treatment than at the time the ointment was dispensed. However, 15 to 100 
percent of the (diminishing) total community burden at each of the final three time points was found among subjects who had received tetracycline at the previous evaluation. In general, the evidence supporting the efficacy of tetracycline is weak. ${ }^{29}$ Many people who receive a prescription for a six-week course probably fail to complete it. ${ }^{25,30}$ In the present study, as in control programs, compliance with tetracycline treatment was not monitored.

Children less than 10 years old accounted for at least 90 percent of the total burden of ocular chlamydial infection at each time point except the 12-month follow-up (Table 2), when one 13-year-old immigrant accounted for a large fraction of the total community burden. In contrast, the contribution of subjects with active disease to the total community reservoir of ocular chlamydiae was less consistent over time. From a programmatic viewpoint, this distinction is important: accurate clinical grading requires training and experience, and skilled ophthalmic personnel are scarce in Africa. ${ }^{31}$ Determining children's ages is more straightforward. In Kahe Mpya at baseline, successful treatment exclusively of the 360 children under the age of 10 years ( 37.7 percent of the subvillage's 956 residents) would have eliminated 97.2 percent of the community's chlamydial burden (Table 2). Further work is needed to determine whether this approach could be an effective and acceptable alternative to mass treatment.

The prevalence of clinically active disease was significantly higher at 12 months than at either 6 or 18 months, whereas both the prevalence and the intensity of ocular $C$. trachomatis infection showed a consistent downward trend over these three time points. Seasonal fluctuations in nonchlamydial ocular pathogens might be responsible for this trend: it has been hypothesized that a variety of microorganisms induce conjunctival changes that are reminiscent of active trachoma in persons who have previously had ocular chlamydial infections. ${ }^{14}$

Our results are extremely encouraging. They have three major implications. First, it seems likely that the observed magnitude and duration of the quantitative reduction in infection were principally due to high baseline treatment coverage, which approached the 100 percent coverage assumed in the model devised by Lietman et al. ${ }^{11}$ Routine, community-based distribution of antibiotics for trachoma control in Tanzania results in a much lower rate of coverage, averaging 80 to 90 percent. Operational research is needed to explore the reasons for the incomplete acceptance of offered antibiotic therapy. Screening and distribution of tetracycline to those with active disease after mass treatment may also have contributed to our dramatic results. If screening and tetracycline treatment are shown to be important, this approach should not be dismissed as a possible adjuvant to baseline mass treatment, especially if such a strategy is critical for local elimination of trachoma.

Second, if near-complete coverage can be obtained, treatment with azithromycin less frequently than every 12 months may be effective. Trials comparing the effect of current practice with that of extended treatment intervals should be a priority. The predicted need for reduced dosing intervals in areas with a very high prevalence of disease ${ }^{11}$ also requires investigation. 
Third, signs of active trachoma have again ${ }^{13}$ proved unhelpful as indicators of the effect of treatment. The prevalence of trachomatous inflammation-follicular among children one to nine years of age was 36.0 percent at baseline, 13.2 percent at two months, and 16.3 percent at two years, yet the community load of ocular $C$. trachomatis infection fell by more than 99 percent during this interval. Possible reasons for the discrepancy between the prevalence of infection and the prevalence of disease have been discussed previously. ${ }^{32}$ An accurate, inexpensive, and rapid $C$. trachomatis assay that can be used in the field to estimate the prevalence of ocular infection in a given community is required for areas in which antibiotics have been distributed or in which the prevalence of active disease is low at the first assessment. ${ }^{12,14}$ Such a test would help program managers to direct antibiotics to the communities that need them most and to measure progress toward the elimination of trachoma.

\section{Acknowledgments}

We are indebted to the village chairmen, elders, and villagers of Kahe Mpya for their good humor and willingness to be involved; to our field teams for help with collection of data and specimens; to Dr. Shanshan Li and Ewen Cameron for excellent laboratory assistance; and to the members of our research steering committee. This study was supported by grants from the Wellcome Trust/Burroughs Wellcome Fund (059134), the Edna McConnell Clark Foundation (99100), the International Trachoma Initiative (01-032), and the Medical Research Council (9826361).

Presented in part at the Research in Progress Meeting of the Royal Society of Tropical Medicine and Hygiene, London, December 12, 2002.

\section{References}

1. Grayston JT, Wang SP, Yeh LJ, Kuo CC. Importance of reinfection in the pathogenesis of trachoma. Rev Infect Dis. 1985; 7:717-25. [PubMed: 4070905]

2. Thylefors B, Negrel AD, Pararajasegaram R, Dadzie KY. Global data on blindness. Bull World Health Organ. 1995; 73:115-21. [PubMed: 7704921]

3. Thylefors B. Development of trachoma control programs and the involvement of national resources. Rev Infect Dis. 1985; 7:774-6. [PubMed: 4070913]

4. Schachter J. Rifampin in chlamydial infections. Rev Infect Dis. 1983; 5(Suppl 3):S562-S564. [PubMed: 6635446]

5. Taylor HR. Trachoma — the future for a disease of the past. Br J Ophthalmol. 1993; 77:66-7. [PubMed: 8435420]

6. Bailey RL, Arullendran P, Whittle HC, Mabey DC. Randomised controlled trial of single-dose azithromycin in treatment of trachoma. Lancet. 1993; 342:453-6. [PubMed: 8102427]

7. Tabbara KF, Abu-el-Asrar A, al-Omar O, Choudhury AH, al-Faisal Z. Single-dose azithromycin in the treatment of trachoma: a randomized, controlled study. Ophthalmology. 1996; 103:842-6. [PubMed: 8637698]

8. Dawson CR, Schachter J, Sallam S, Sheta A, Rubinstein RA, Washton H. A comparison of oral azithromycin with topical oxytetracycline/polymyxin for the treatment of trachoma in children. Clin Infect Dis. 1997; 24:363-8. [PubMed: 9114186]

9. Schachter J, West SK, Mabey D, et al. Azithromycin in control of trachoma. Lancet. 1999; 354:6305. [PubMed: 10466664]

10. Bowman RJ, Sillah A, Van Dehn C, et al. Operational comparison of single-dose azithromycin and topical tetracycline for trachoma. Invest Ophthalmol Vis Sci. 2000; 41:4074-9. [PubMed: 11095598]

11. Lietman T, Porco T, Dawson C, Blower S. Global elimination of trachoma: how frequently should we administer mass chemotherapy? Nat Med. 1999; 5:572-6. [PubMed: 10229236] 
12. Thein J, Zhao P, Liu H, et al. Does clinical diagnosis indicate ocular chlamydial infection in areas with a low prevalence of trachoma? Ophthalmic Epidemiol. 2002; 9:263-9. [PubMed: 12187424]

13. Bird M, Dawson CR, Schachter JS, et al. Does the diagnosis of trachoma adequately identify ocular chlamydial infection in trachoma-endemic areas? J Infect Dis. 2003; 187:1669-73. [PubMed: 12721948]

14. Baral K, Osaki S, Shreshta B, et al. Reliability of clinical diagnosis in identifying infectious trachoma in a low-prevalence area of Nepal. Bull World Health Organ. 1999; 77:461-6. [PubMed: 10427930]

15. Solomon AW, Holland MJ, Burton MJ, et al. Strategies for control of trachoma: observational study with quantitative PCR. Lancet. 2003; 362:198-204. [PubMed: 12885481]

16. Thylefors B, Dawson CR, Jones BR, West SK, Taylor HR. A simple system for the assessment of trachoma and its complications. Bull World Health Organ. 1987; 65:477-83. [PubMed: 3500800]

17. Rothman, KJ, Greenland, S. Modern epidemiology. 2nd ed. Philadelphia: Lippincott-Raven; 1998.

18. West SK, Munoz B, Mkocha H, Hsieh YH, Lynch MC. Progression of active trachoma to scarring in a cohort of Tanzanian children. Ophthalmic Epidemiol. 2001; 8:137-44. [PubMed: 11471083]

19. Schachter, J; Moncada, J. Nucleic acid amplification tests to diagnose Chlamydia trachomatis genital infection - the glass is more than half full. In: Schachter, J; Christiansen, G; Clarke, IN; , et al., editors. Chlamydial infections: Proceedings of the 10th International Symposium on Human Chlamydial Infections; Antalya, Turkey. June, 16-21, 2002; San Francisco: International Chlamydia Symposium; 2002.

20. Shattock RM, Patrizio C, Simmonds P, Sutherland S. Detection of Chlamydia trachomatis in genital swabs: comparison of commercial and in house amplification methods with culture. Sex Transm Infect. 1998; 74:289-93. [PubMed: 9924472]

21. Liang K-Y, Zeger SL. Longitudinal data analysis using generalized linear models. Biometrika. 1986; 73:13-22.

22. Kirkwood, BR. Essentials of medical statistics. Oxford, England: Blackwell Science; 1988.

23. Everett K, Bush RM, Andersen AA. Emended description of the order Chlamydiales, proposal of Parachlamydiaceae fam. nov. and Simkaniaceae fam. nov., each containing one monotypic genus, revised taxonomy of the family Chlamydiaceae, including a new genus and five new species, and standards for the identification of organisms. Int J Syst Bacteriol. 1999; 49:415-40. [PubMed: 10319462]

24. Schachter J. Overview of Chlamydia trachomatis infection and the requirements for a vaccine. Rev Infect Dis. 1985; 7:713-6. [PubMed: 3840910]

25. Kuper H, Solomon AW, Buchan J, Zondervan M, Foster A, Mabey D. A critical review of the SAFE strategy for the prevention of blinding trachoma. Lancet Infect Dis. 2003; 3:372-81. [PubMed: 12781509]

26. West S, Munoz B, Lynch M, et al. Impact of face-washing on trachoma in Kongwa, Tanzania. Lancet. 1995; 345:155-8. [PubMed: 7823670]

27. Emerson PM, Lindsay SW, Walraven GE, et al. Effect of fly control on trachoma and diarrhoea. Lancet. 1999; 353:1401-3. [PubMed: 10227221]

28. Jha H, Chaudary JS, Bhatta R, et al. Disappearance of trachoma from Western Nepal. Clin Infect Dis. 2002; 35:765-8. [PubMed: 12203176]

29. Mabey D, Solomon A. The effect of antibiotic treatment on active trachoma and ocular Chlamydia trachomatis infection. Expert Rev Antiinfect Ther. 2003; 1:209-16.

30. Thylefors B. Prevention of blindness - WHO's mission for vision. World Health Forum. 1998; 19:53-9. [PubMed: 9610242]

31. Foster A. Who will operate on Africa's 3 million curably blind people? Lancet. 1991; 337:1267-9. [PubMed: 1674072]

32. Mabey DC, Solomon AW, Foster A. Trachoma. Lancet. 2003; 362:223-9. [PubMed: 12885486] 


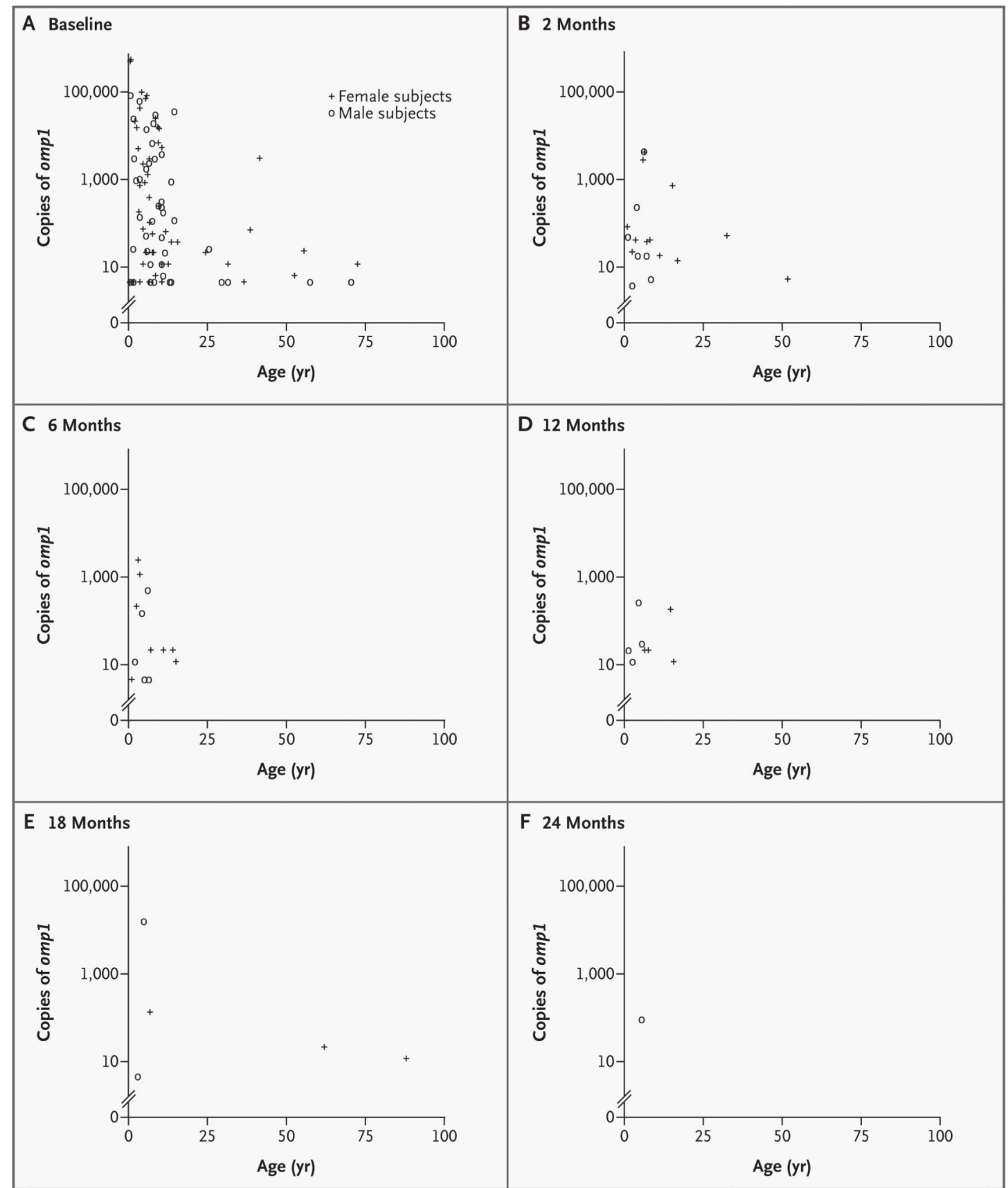

Figure 1. Number of Copies of omp1 per Swab According to Age and Sex at Baseline (Panel A), 2 Months (Panel B), 6 Months (Panel C), 12 Months (Panel D), 18 Months (Panel E), and 24 Months (Panel F).

Swabs that were negative on a highly sensitive PCR assay are not shown. 


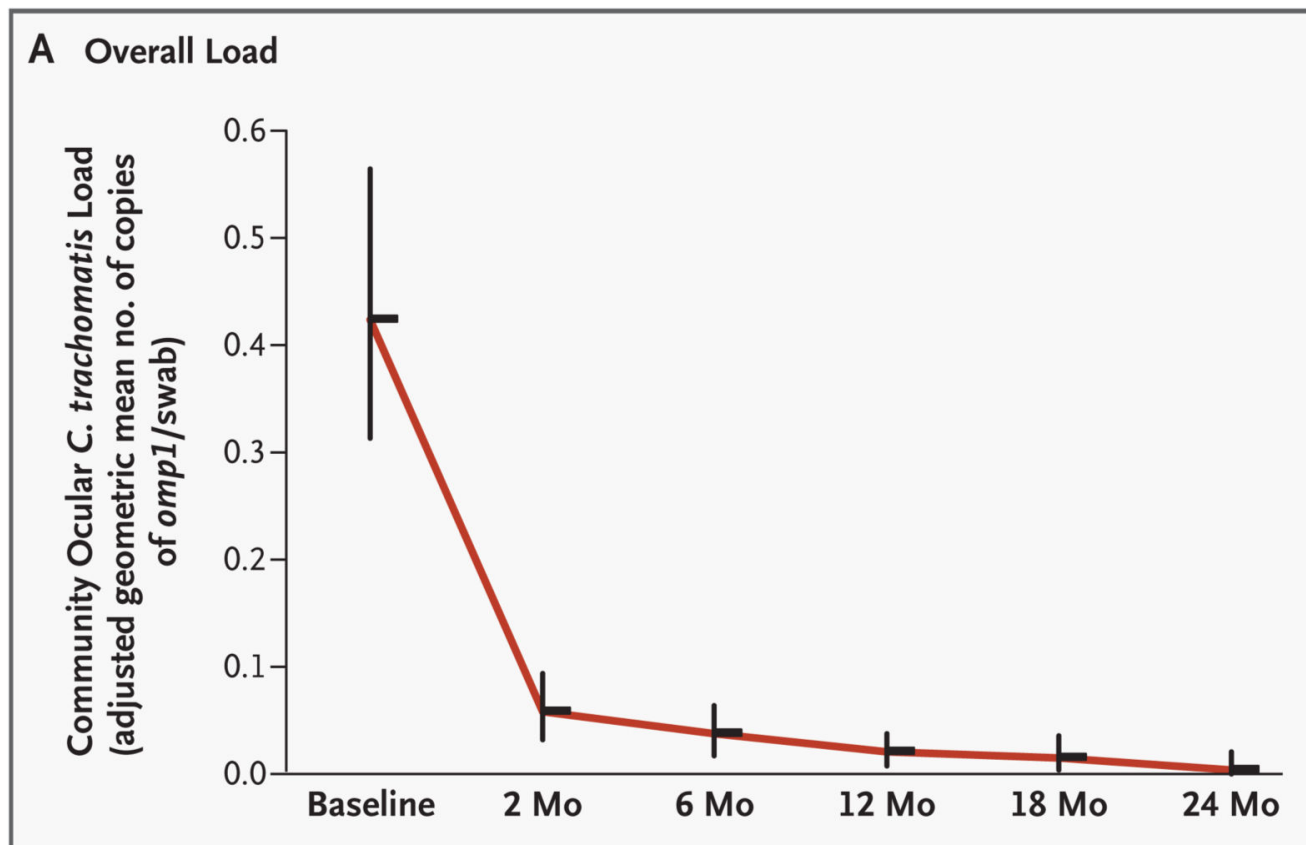

B Age-Specific Load

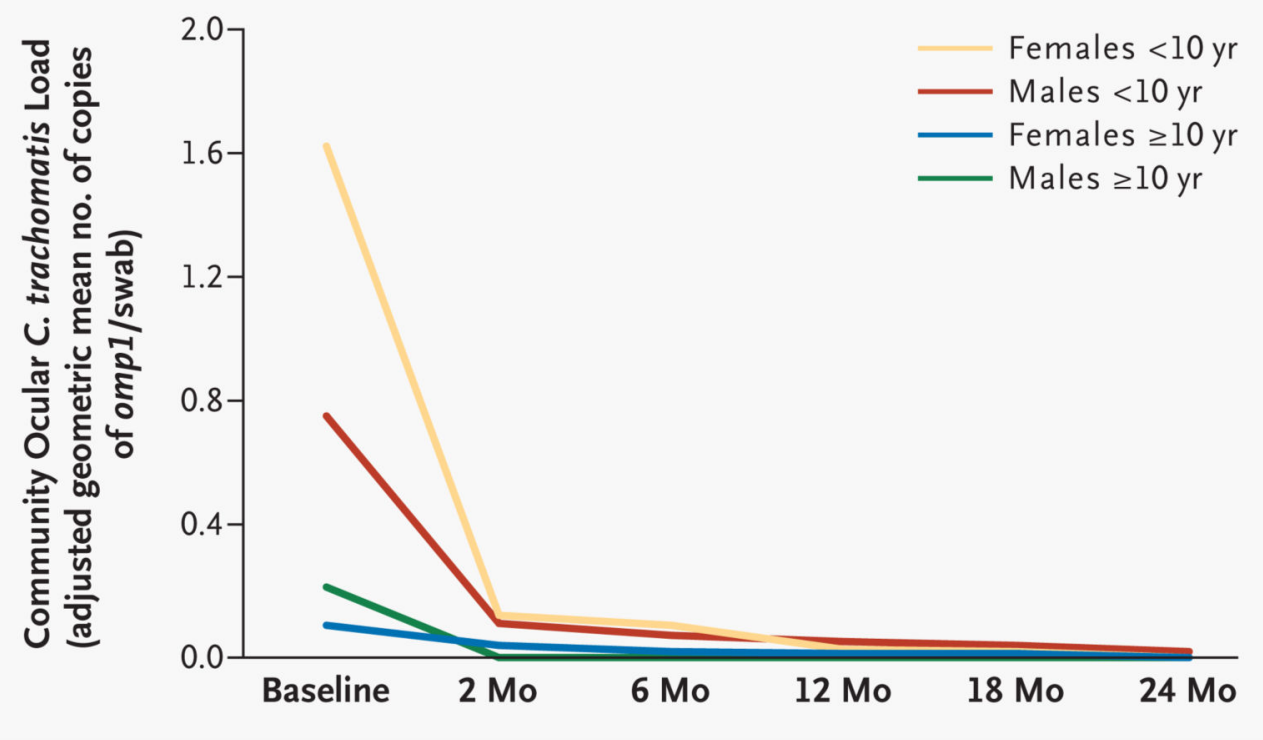

Figure 2. Overall (Panel A) and Age-Specific (Panel B) Community Ocular Chlamydia trachomatis Load at Each Time Point.

Vertical bars in Panel A are 95 percent confidence intervals. 


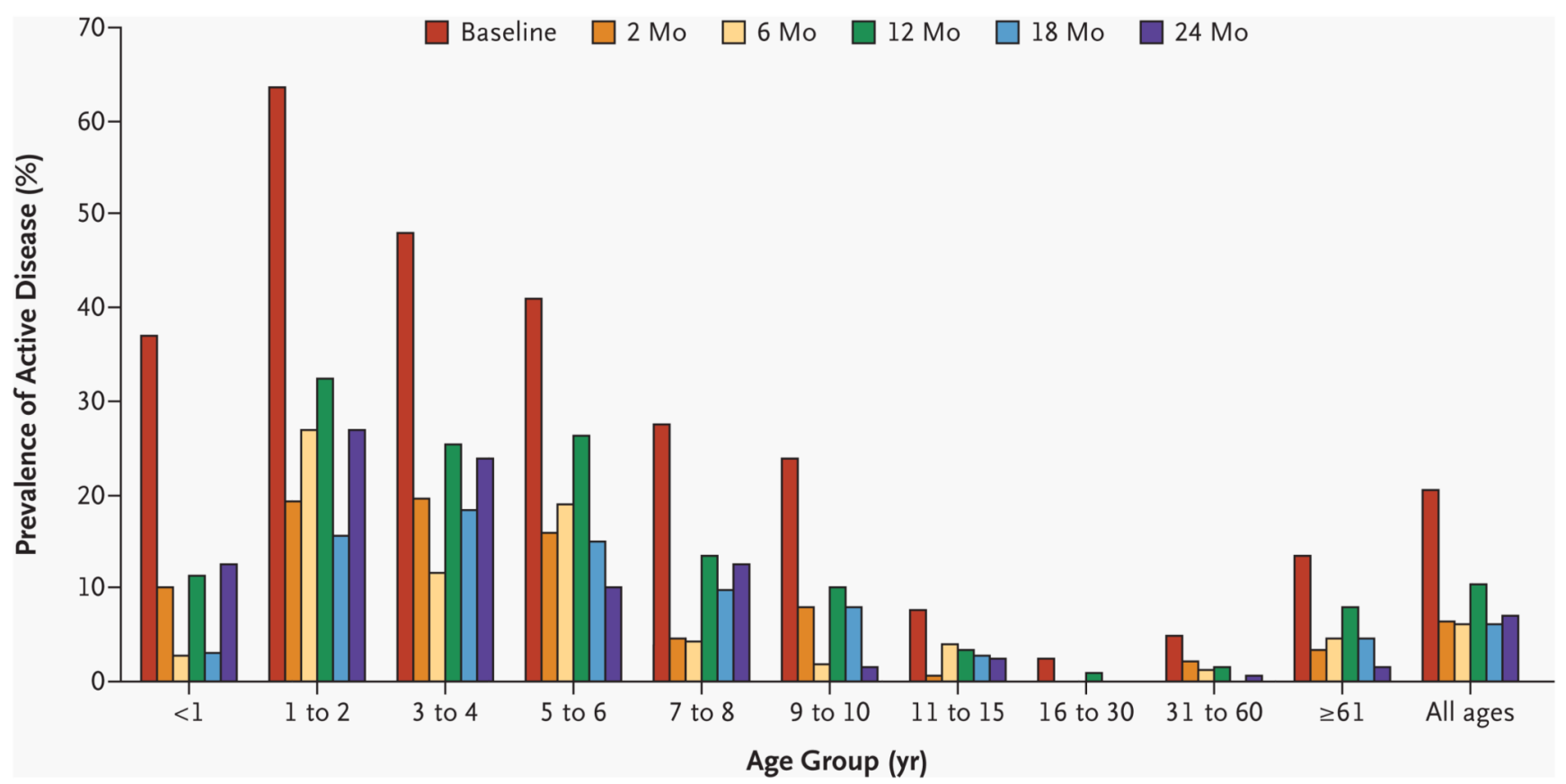

Figure 3. Prevalence of Active Disease over Time among the Various Age Groups.

Active disease was defined according to the World Health Organization simplified grading system, by the presence of trachomatous inflammation-follicular, trachomatous inflammation-intense, or both in either eye. 
Table 1

Subjects with Swabs Positive for Chlamydia trachomatis and the Community Ocular $C$. trachomatis Load.

\begin{tabular}{|c|c|c|c|c|c|}
\hline \multirow[t]{2}{*}{ Time } & \multirow[t]{2}{*}{$\begin{array}{l}\text { Total No. of } \\
\text { Residents }\end{array}$} & \multirow[t]{2}{*}{ Subjects Tested } & \multirow[t]{3}{*}{$\begin{array}{l}\text { Subjects with Positive } \\
\text { Swabs }\end{array}$} & \multicolumn{2}{|c|}{ Community Ocular C. trachomatis Load* } \\
\hline & & & & Adjusted Geometric Mean (95\% CI) & $\%$ of Baseline \\
\hline \multicolumn{5}{|c|}{ number (percent) } & \\
\hline Baseline & 978 & $956(97.8)$ & $91(9.5)$ & $0.423(0.312-0.564)$ & 100.0 \\
\hline 2 Months & 959 & $905(94.4)$ & $19(2.1)$ & $0.059(0.032-0.094)$ & $13.9^{\dagger}$ \\
\hline 6 Months & 973 & $879(90.3)$ & $13(1.5)$ & $0.037(0.018-0.064)$ & $8.7^{\dagger}$ \\
\hline 12 Months & 984 & $907(92.2)$ & $8(0.9)$ & $0.020(0.008-0.037)$ & $4.7^{\dagger}$ \\
\hline 18 Months & 978 & $889(90.9)$ & $5(0.6)$ & $0.015(0.003-0.036)$ & $3.6^{\dagger}$ \\
\hline 24 Months & 985 & $842(85.5)$ & $1(0.1)$ & $0.003(0-0.020)$ & $0.8^{\dagger}$ \\
\hline
\end{tabular}

The community ocular $C$. trachomatis load is the adjusted geometric mean of the number of copies of omp1, determined by quantitative PCR, in the swab obtained from each subject at each time point. CI denotes confidence interval.

${ }^{\dagger} \mathrm{P}<0.001$ for the comparison with the baseline value. 
Table 2

Distribution of the Total Community Ocular Chlamydia trachomatis Load among Various Subgroups of the Population at Each Time Point.*

\begin{tabular}{|c|c|c|c|c|c|c|}
\hline $\begin{array}{l}\text { Variable } \\
\text { Clinical signs of trachoma }{ }^{\dagger}\end{array}$ & $\begin{array}{l}\text { Baseline } \\
(\mathrm{N}=956)\end{array}$ & $\begin{array}{l}2 \text { Months } \\
(\mathrm{N}=905)\end{array}$ & $\begin{array}{l}6 \text { Months } \\
(\mathrm{N}=879)\end{array}$ & $\begin{array}{l}12 \text { Months } \\
(\mathrm{N}=907)\end{array}$ & $\begin{array}{l}18 \text { Months } \\
(\mathrm{N}=\mathbf{8 8 9})\end{array}$ & $\begin{array}{l}24 \text { Months } \\
(\mathrm{N}=842)\end{array}$ \\
\hline \multicolumn{7}{|l|}{ TF, TI, or both } \\
\hline $\begin{array}{l}\text { Percentage of total copies } \\
\text { of omp1 }\end{array}$ & 98.1 & 70.7 & 40.0 & 62.0 & 99.8 & 100 \\
\hline $\begin{array}{l}\text { No. positive/total no. of } \\
\text { subjects }\end{array}$ & $58 / 174$ & $9 / 49$ & $6 / 42$ & $5 / 77$ & $3 / 43$ & $1 / 49$ \\
\hline \multicolumn{7}{|l|}{ TI with or without TF } \\
\hline $\begin{array}{l}\text { Percentage of total copies } \\
\text { of omp1 }\end{array}$ & 92.4 & 33.9 & 28.6 & 0 & 99.0 & 100 \\
\hline $\begin{array}{l}\text { No. positive/total no. of } \\
\text { subjects }\end{array}$ & $41 / 111$ & $5 / 24$ & $3 / 25$ & $0 / 30$ & $2 / 22$ & $1 / 14$ \\
\hline \multicolumn{7}{|l|}{ TI but not TF } \\
\hline $\begin{array}{l}\text { Percentage of total copies } \\
\text { of omp1 }\end{array}$ & 65.6 & 0.7 & 0 & 0 & 0 & 0 \\
\hline $\begin{array}{l}\text { No. positive/total no. of } \\
\text { subjects }\end{array}$ & $11 / 56$ & $1 / 9$ & $0 / 14$ & $0 / 18$ & $0 / 11$ & $0 / 10$ \\
\hline \multicolumn{7}{|l|}{ TF with or without TI } \\
\hline $\begin{array}{l}\text { Percentage of total copies } \\
\text { of omp1 }\end{array}$ & 32.5 & 70.0 & 40.0 & 62.0 & 99.8 & 100 \\
\hline $\begin{array}{l}\text { No. positive/total no. of } \\
\text { subjects }\end{array}$ & $47 / 118$ & $8 / 40$ & $6 / 28$ & $5 / 59$ & $3 / 32$ & $1 / 39$ \\
\hline \multicolumn{7}{|l|}{ Both TF and TI } \\
\hline $\begin{array}{l}\text { Percentage of total copies } \\
\text { of omp1 }\end{array}$ & 26.9 & 33.3 & 28.6 & 0 & 99.0 & 100 \\
\hline $\begin{array}{l}\text { No. positive/total no. of } \\
\text { subjects }\end{array}$ & $30 / 55$ & $4 / 15$ & $3 / 11$ & $0 / 12$ & $2 / 11$ & $1 / 4$ \\
\hline \multicolumn{7}{|l|}{ TF but not TI } \\
\hline $\begin{array}{l}\text { Percentage of total copies } \\
\text { of omp1 }\end{array}$ & 5.7 & 36.8 & 11.4 & 62.0 & 0.8 & 0 \\
\hline $\begin{array}{l}\text { No. positive/total no. of } \\
\text { subjects }\end{array}$ & $17 / 63$ & $4 / 25$ & $3 / 17$ & $5 / 47$ & $1 / 21$ & $0 / 35$ \\
\hline \multicolumn{7}{|l|}{ Neither TF nor TI } \\
\hline $\begin{array}{l}\text { Percentage of total copies } \\
\text { of omp1 }\end{array}$ & 1.9 & 29.3 & 60.0 & 38.2 & 0.2 & 0 \\
\hline $\begin{array}{l}\text { No. positive/total no. of } \\
\text { subjects }\end{array}$ & $33 / 782$ & $10 / 855$ & $7 / 837$ & $3 / 830$ & $2 / 846$ & $0 / 793$ \\
\hline Sex and age group & & & & & & \\
\hline
\end{tabular}




\begin{tabular}{|c|c|c|c|c|c|c|}
\hline Variable & $\begin{array}{l}\text { Baseline } \\
(\mathrm{N}=956)\end{array}$ & $\begin{array}{c}2 \text { Months } \\
\text { (N=905) }\end{array}$ & $\begin{array}{c}\text { 6 Months } \\
\text { (N=879) }\end{array}$ & $\begin{array}{l}12 \text { Months } \\
\text { (N=907) }\end{array}$ & $\begin{array}{l}18 \text { Months } \\
(\mathrm{N}=889)\end{array}$ & $\begin{array}{l}24 \text { Months } \\
\text { (N=842) }\end{array}$ \\
\hline $\begin{array}{l}\text { Percentage of total copies } \\
\text { of omp1 }\end{array}$ & 82.7 & 56.5 & 84.0 & 7.6 & 0.8 & 0 \\
\hline $\begin{array}{l}\text { No. positive/total no. of } \\
\text { subjects }\end{array}$ & $33 / 174$ & $7 / 177$ & $5 / 164$ & $2 / 177$ & $1 / 172$ & $0 / 164$ \\
\hline \multicolumn{7}{|l|}{ Males $<10 \mathrm{yr}$} \\
\hline $\begin{array}{l}\text { Percentage of total copies } \\
\text { of omp1 }\end{array}$ & 14.4 & 36.9 & 14.8 & 58.3 & 98.9 & 100 \\
\hline $\begin{array}{l}\text { No. positive/total no. of } \\
\text { subjects }\end{array}$ & $24 / 186$ & $7 / 174$ & $5 / 167$ & $4 / 177$ & $2 / 176$ & $1 / 168$ \\
\hline \multicolumn{7}{|l|}{ Females $\geq 10 \mathrm{yr}$} \\
\hline $\begin{array}{l}\text { Percentage of total copies } \\
\text { of omp1 }\end{array}$ & 0.5 & 6.5 & 1.2 & $34.2 \%$ & 0.2 & 0 \\
\hline $\begin{array}{l}\text { No. positive/total no. of } \\
\text { subjects }\end{array}$ & $16 / 360$ & $5 / 338$ & $3 / 329$ & $2 / 340$ & $2 / 329$ & $0 / 317$ \\
\hline \multicolumn{7}{|l|}{ Males $\geq 10 \mathrm{yr}$} \\
\hline $\begin{array}{l}\text { Percentage of total copies } \\
\text { of omp1 }\end{array}$ & 2.3 & 0 & 0 & 0 & 0 & 0 \\
\hline $\begin{array}{l}\text { No. positive/total no. of } \\
\text { subjects }\end{array}$ & $18 / 236$ & $0 / 216$ & $0 / 219$ & $0 / 213$ & $0 / 212$ & $0 / 193$ \\
\hline \multicolumn{7}{|l|}{ Time of enrollment or positivity } \\
\hline \multicolumn{7}{|l|}{ Enrollment after baseline $\xi$} \\
\hline $\begin{array}{l}\text { Percentage of total copies } \\
\text { of omp1 }\end{array}$ & NA & 0.1 & 0.5 & 32.3 & 0 & 0 \\
\hline $\begin{array}{l}\text { No. positive/total no. of } \\
\text { subjects }\end{array}$ & NA & $1 / 29$ & $1 / 74$ & $1 / 126$ & $0 / 162$ & $0 / 195$ \\
\hline \multicolumn{7}{|c|}{ Receipt of tetracycline at this time point } \\
\hline $\begin{array}{l}\text { Percentage of total copies } \\
\text { of omp1 }\end{array}$ & NA & $\mathrm{NA}^{\text {II }}$ & 44.7 & 61.9 & 99.8 & NA \\
\hline $\begin{array}{l}\text { No. positive/total no. of } \\
\text { subjects }\end{array}$ & NA & NA & $7 / 54$ & $5 / 94$ & $3 / 54$ & NA \\
\hline \multicolumn{7}{|c|}{ Previous treatment with tetracycline } \\
\hline $\begin{array}{l}\text { Percentage of total copies } \\
\text { of omp1 }\end{array}$ & NA & NA & NA & 15.0 & 99.8 & 100 \\
\hline $\begin{array}{l}\text { No. positive/total no. of } \\
\text { subjects }\end{array}$ & NA & NA & NA & $4 / 54$ & $3 / 94$ & $1 / 54$ \\
\hline \multicolumn{7}{|l|}{ Subjects not previously positive $/$ " } \\
\hline $\begin{array}{l}\text { Percentage of total copies } \\
\text { of omp1 }\end{array}$ & NA & 6.7 & 0.9 & 7.6 & 0.2 & 0 \\
\hline $\begin{array}{l}\text { No. positive/total no. of } \\
\text { subjects }\end{array}$ & NA & $7 / 817$ & $4 / 863$ & $2 / 894$ & $2 / 882$ & $0 / 836$ \\
\hline \multicolumn{7}{|l|}{ Previously positive subjects ${ }^{* *}$} \\
\hline $\begin{array}{l}\text { Percentage of total copies } \\
\text { of omp1 }\end{array}$ & NA & 93.3 & 99.1 & 92.4 & 99.8 & 100 \\
\hline
\end{tabular}




\begin{tabular}{|c|c|c|c|c|c|c|}
\hline Variable & $\begin{array}{l}\text { Baseline } \\
(\mathbf{N}=956)\end{array}$ & $\begin{array}{l}2 \text { Months } \\
\text { (N=905) }\end{array}$ & $\begin{array}{l}6 \text { Months } \\
(\mathrm{N}=879)\end{array}$ & $\begin{array}{l}12 \text { Months } \\
(\mathrm{N}=907)\end{array}$ & $\begin{array}{l}18 \text { Months } \\
(\mathrm{N}=\mathbf{8 8 9})\end{array}$ & $\begin{array}{l}24 \text { Months } \\
(\mathrm{N}=842)\end{array}$ \\
\hline $\begin{array}{l}\text { No. positive/total no. of } \\
\text { subjects }\end{array}$ & NA & $12 / 88$ & $9 / 16$ & $6 / 13$ & $3 / 7$ & $1 / 6$ \\
\hline \multicolumn{7}{|l|}{ All subjects } \\
\hline $\begin{array}{l}\text { Percentage of total copies of } \\
\text { omp1 }\end{array}$ & 100 & 100 & 100 & 100 & 100 & 100 \\
\hline $\begin{array}{l}\text { No. positive/total no. of } \\
\text { subjects }\end{array}$ & $91 / 956$ & $19 / 905$ & $13 / 879$ & $8 / 907$ & $5 / 889$ & $1 / 842$ \\
\hline
\end{tabular}

The percentage of total copies is the percentage of the total contributed by each subgroup. TF denotes trachomatous inflammation-follicular, TI trachomatous inflammation-intense, and NA not applicable.

${ }^{\dagger}$ C. trachomatis burden in groups with different clinical signs in the swabbed eye is given. Active disease was defined according to the World Health Organization simplified grading system. The sum of the percentages for the various subgroups at each time point exceeds 100 percent because the clinical categories used are not mutually exclusive. Examination data were missing for one ( $C$. trachomatis-negative) subject at two months.

t

${ }^{7}$ The principal contribution to the relatively high percentage of the total burden among female subjects 10 years of age or older at 12 months was from a 13-year-old girl whose positive result represented 32 percent of the community burden of $C$. trachomatis infection at that time point. She had arrived between five and six months after baseline and therefore had not received azithromycin.

$\xi_{\text {Subjects who arrived after baseline included those who were born after baseline and those who immigrated to the subvillage after baseline and }}$ who therefore had not been present at the time of mass treatment.

I/No tetracycline was distributed at two months.

"Subjects who were not previously positive were those who had not been positive the previous time they were tested or who had not previously been tested.

**

Previously positive subjects were those who had been positive the previous time they were tested. 